\title{
PELATIHAN KETERAMPILAN USAHA KREATIF WARGA RW 8 KELURAHAN CIUMBULEUIT KECAMATAN CIDADAP KOTA BANDUNG
}

\author{
Lina Said \\ linasaid312@yahoo.com \\ Reni Marlina \\ reni.marlina@ekuitas.ac.id \\ Yudi Wahyudin \\ yudisuwandi@gmail.com
}

\section{SEKOLAH TINGGI ILMU EKONOMI EKUITAS}

\begin{abstract}
ABSTRAK
Kawasan Dago adalah salah satu tujuan wisata di Kota Bandung. Setiap menjelang akhir pekan kawasan Dago ini dipenuhi wisatawan baik mancanegara maupun lokal. Salah satu daerah yang potensial adalah kawasan Curug Dago. Potensi daerah ini cukup bagus sebagai tujuan wisata. Namun banyak warganya, terutama ibu rumah tangga melakukan pekerjaan sebagai asisten rumah tangga di sekitar $R W$ 8, karena disana banyak kawasan perumahan (Kompleks ITB, UNPAD, Sekolah Alam, dll.), sehingga tingkat kesejahteraannya masih rendah. Untuk pemberdayaan masyarakat $R W 8$ ini diberikan pelatihan mengenai pembuatan produk dan pelatihan manajemen usaha. Ibu-ibu Warga $R W 8$ diberikan pelatihan tentang pembuatan kue, agar warganya produktif dan dapat membuat produk kue yang dapat dijajakan di daerah wisata Curug Dago. Warganya cukup antusias, dan mengikuti praktik membuat kue hingga selesai. Adapun hasil dari pengabdian ini adalah menambah pengetahuan dalam membuat produk serta warga lebih memahami dalam menghitung biaya produksi, sehingga meminimalisasi terjadinya kerugian apabila melakukan kegiatan usaha.
\end{abstract}

Kata kunci: Pemberdayaan Masyarakat.

\section{PENDAHULUAN}

Kota Bandung dikenal dengan tujuan wisatanya dan kuliner. Kota Bandung terbagi menjadi 30 kecamatan, diantaranya Kec. Bandung Wetan, Sumur Bandung, Kiaracondong, Panyileukan, Coblong, Cidadap, Lengkong, Batununggal, Arcamanik, Regol, dll.
Tempat wisata tersebut tersebar pada beberapa daerah, terutama kawasan Dago yang salah satunya masuk ke Kec. Cidadap, yang telah dikenal oleh masyarakat luas sebagai pusat/daerah wisata. Setiap menjelang akhir pekan kawasan Dago ini dipenuhi wisatawan baik mancanegara maupun lokal. Daerah ini dikenal dengan ketinggiannya yang membuat udaranya lebih sejuk dibandingkan daerah lainnya, sehingga potensi ekonomi masayarakat 
berkembang pesat. Hal ini menjadi peluang bagi masyarakat sekitarnya untuk membuka usaha, terutama bidang kuliner.

Salah satu wilayah yang dapat dikembangkan potensi ekonominya yaitu kawasan Curug Dago yang terletak di Desa Dago, Kec. Coblong, Kota Bandung, Jawa Barat, Pulau Jawa,Indonesia. Terletak sekitar $8 \mathrm{~km}$ dari pusat kota Bandung menuju arah utara. Curug Dago ini berbatasan langsung dengan RW 8, kelurahan Ciumbuleuit, Kec. Cidadap. Keberadaan RW 8 ini berbatasan langsung dengan TAHURA (Taman Hutan Raya) JUANDA.

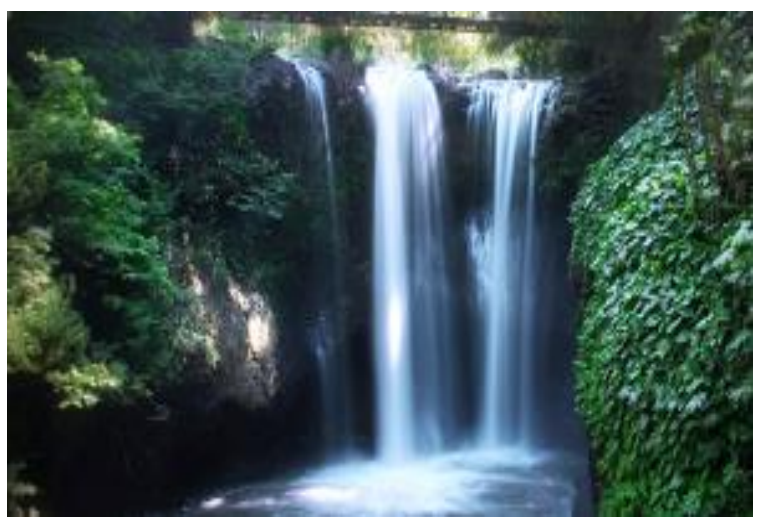

Gambar 1. Curug Dago

Karena cukup strategis, kawasan ini menjadi jalur akses jalan menuju Curug Dago. Potensi daerah ini cukup bagus sebagai tujuan wisata. Bahkan Ibu Imas sebagai Ketua RW-nya selalu berusaha memberdayakan warganya. Namun banyak warganya, terutama ibu rumah tangga bekerja sebagai asisten rumah tangga di sekitar RW 8, karena disana banyak kawasan perumahan (Kompleks ITB, UNPAD, Sekolah Alam, dll.), sehingga tingkat kesejahteraannya masih rendah.

Berdasarkan survey pendahuluan, dan hasil wawancara dengan Ketua RW 8, Ibu Imas menyatakan keinginan pemberdayaan kepada warganya terutama ibu-ibu rumah tangga agar mempunyai keahlian di bidang usaha tertentu, sehingga berpeluang membuka usaha. Pada akhirnya dapat meningkatkan kesejahteraan masyarakat RW 8.

Usaha yang dapat dilakukan masyarakat adalah membuat produk diantaranya makanan khas yang nantinya dapat dijual/dijajakan di sekitar tempat wisata Curug Dago. Dengan demikian dapat meningkatkan pendapatan masyarakat sekitar tempat wisata tersebut.

Namun permasalahan yang dihadapi oleh warga RW 8 ini adalah:

1. Belum memiliki keahlian bidang tertentu yang bersifat produktif.

2. Belum memahami manajemen usaha dan cara menghitung harga pokok penjualan.

\section{METODE PELAKSANAAN}

Metode pelaksanaan Pemberdayaan masyarakat warga ini antara lain:

a. Melaksanakan pelatihan keterampilan pembuatan produk, dengan mendatangkan tenaga ahli di bidang tertentu, sehingga masyarakat memahami cara membuat produk tertentu yang dapat meningkatkan produktivitas masyarakat RW 8.

b. Melaksanakan pelatihan manajemen usaha termasuk di dalamnya penghitungan harga pokok, agar produk yang dihasilkan nanti dapat digunakan untuk dijual di sekitar kawasan wisata Curug Dago, dan TAHURA sehingga dapat meningkatkan pendapatan masyarakat RW 8.

c. Pemberian pelatihan dilanjutkan dengan tanya jawab.

Metode yang digunakan adalah pelatihan yang terdiri dari pelatihan

1. Pelatihan pembuatan produk kue

2. Pelatihan manajemen usaha termasuk penghitungan harga pokok, juga berkaitan dengan pemasaran produk.

3. Penutup. 
Kelompok sasaran dari kegiatan pengabdian ini adalah warga RW 8. Peran serta masyarakat warga RW 8 dalam program ini sangat mendukung terhadap keberhasilan program. Ibu Imas sebagai Ketua RW 8 akan diberikan peran sebagai ketua kelompok sebagai mentor/trainer bagi anggota kelompok lainnya. Tugas ketua kelompok adalah mampu menggerakkan anggotanya pada saat acara pelatihan pembuatan produk dan pengembangan usaha dengan harapan menghasilkan produk yang dapat dijual dan mengelola usahanya dengan baik

\section{HASIL DAN LUARAN}

Daerah Curug Dago berpotensi untuk tujuan wisata yang bisa dikembangkan. Daerah ini berdekatan dengan warga RW 8, kelurahan Ciumbuleuit, Kec. Cidadap. Warganya terutama perempuan (ibu-ibu) masih berada dalam usia produktif namum tidak banyak keahlian yang dimiliki. Umumnya mereka hanya buruh Cuci baju, atau membantu rumah tangga warga sekitarnya, sehingga bentuk pelatihan yang diberikan kepada ibu-ibu warga RW 8, berupa pembuatan kue taart, bolu gulung, dan bolu apel. Pelatihan lainnya yang diberikan berupa pelatihan manajemen usaha, termasuk penghitungan biaya produksi. Hal ini bertujuan agar warga menjadi lebih produktif dan bisa membuka usaha kuliner di sekitar Kawasan Wisata Curug Dago.

Warga RW 8 diberikan pelatihan sekaligus praktik membuat produk kue yang mudah untuk dibuat seperti bolu gulung, taart "makuta", bolu apel. Warga diberikan pengetahuan tatacara pembuatan kue, mulai dari pemilihan bahan yang baik, cara pembuatan dan pemanggangan yang efektif, hingga penghitungan/kalkulasi harga pokok dan harga jual produk. Dengan demikian, apabila warga akan memproduksi suatu produk dan menjualnya tidak mengalami kerugian.

Warga sangat antusias terhadap materi pelatihan yang diberikan. Salah satu warga menyatakan bahwa sangat tertarik dan senang dengan pelatihan ini, apalagi dapat langsung praktik dipandu oleh ahlinya, sehingga menambah pengetahuan dalam membuat kue serta lebih memahami dalam menghitung biaya produksi, sehingga meminimalisir terjadinya kerugian apabila melakukan kegiatan usaha.
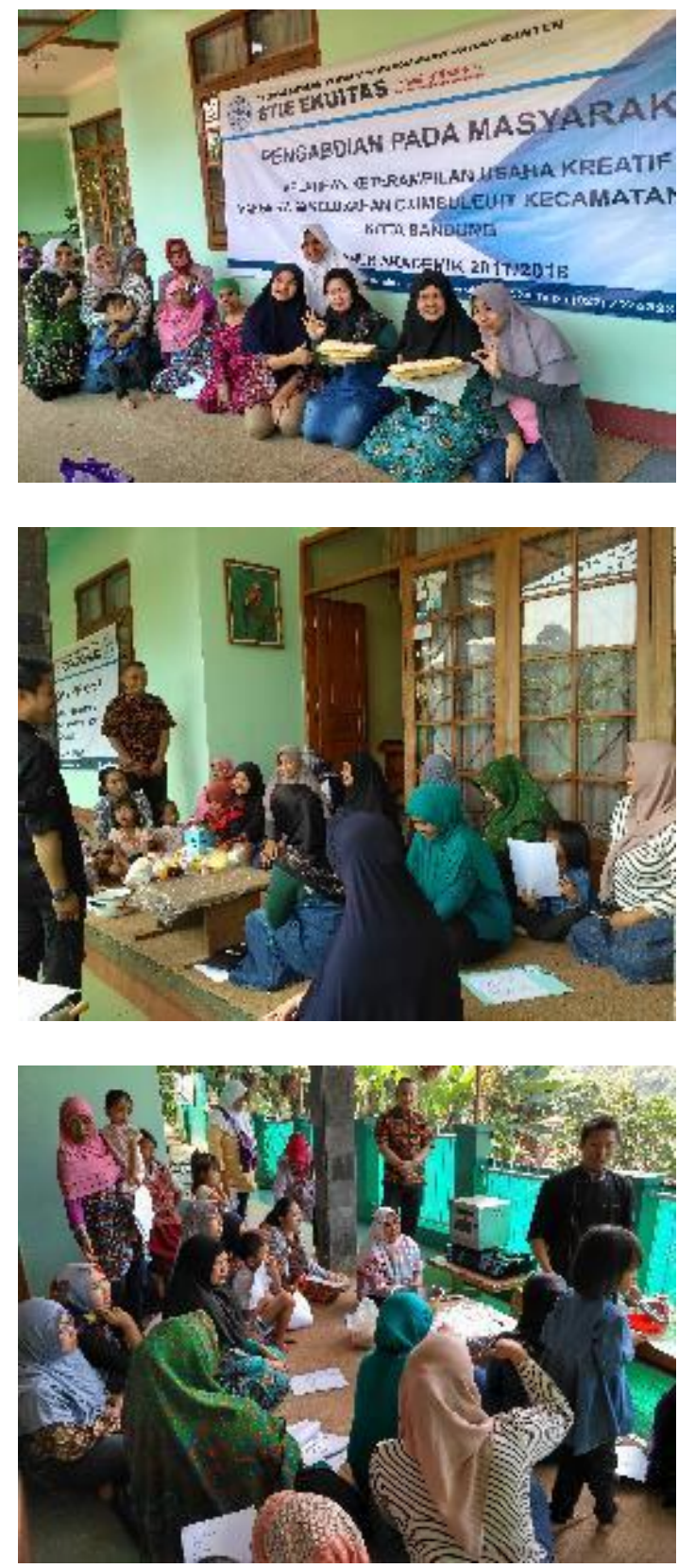

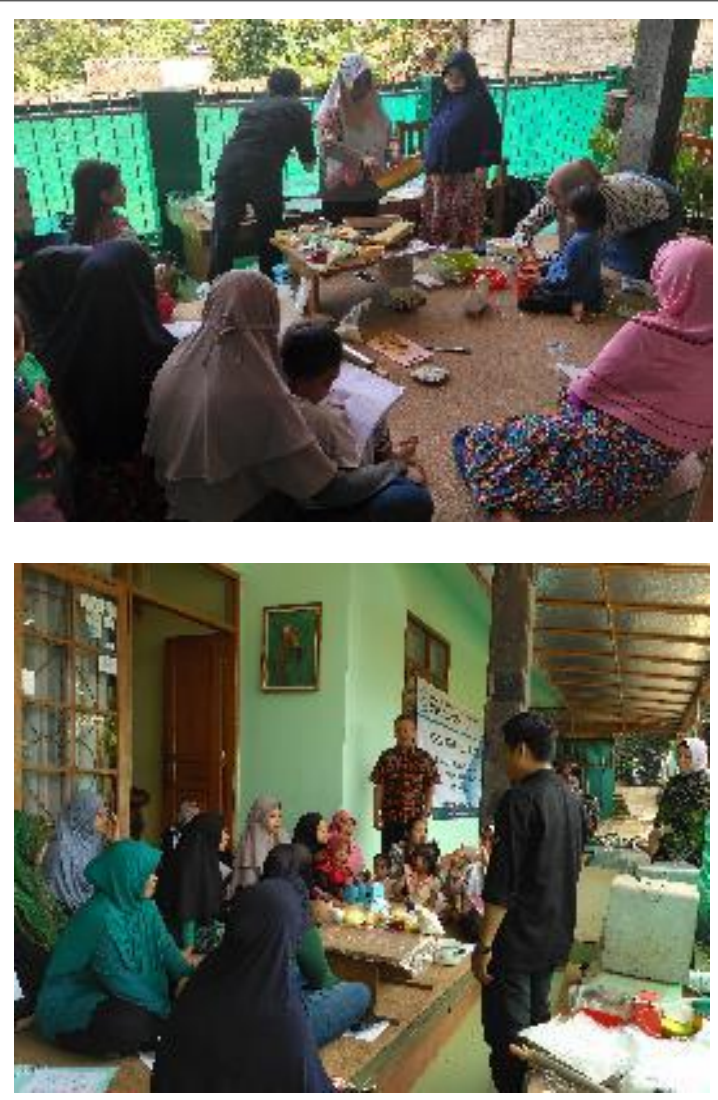

Adapun dampak dari pengabdian bagi masyarakat dalam bentuk pelatihan di RW 8 ini adalah dapat menumbuhkan minat usaha serta menambah wawasan dan pengetahuan warga dalam berwirausaha

\section{KESIMPULAN}

Pengabdian kepada masyarakat dilaksanakan kepada warga RW 8. Materi pelatihan berupa pelatihan pembuatan produk serta manajemen usaha termasuk menghitung harga pokok penjualan suatu produk. Dengan adanya pelatihan ini, dapat menumbuhkan minat usaha serta menambah wawasan dan pengetahuan warga dalam berwirausaha.

\section{DAFTAR PUSTAKA}

Ayu, A., Doni, S. (2013). Pembukuan Sederhana Usaha Dagang dan Jasa. Jakarta: Laskar Aksara.
Hery. (2015). Cara Mudah Membuat Pembukuan Sederhana. Jakarta: Grasindo.

Judy, S., Raymond, F. (2013). E Marketing. Routlegdess.

Kanaidi. (2013). Workshop : e Marketing SMART Technique for Entrepreneurs. Bandung: Politeknik Pos Indonesia. 